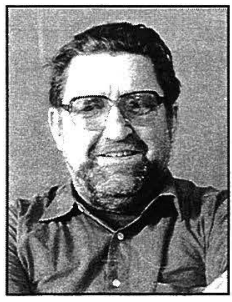

\title{
THE DE-INDUSTRIALIZATION OF NEW ZEALAND
}

\author{
Brian Easton \\ Central Institute of Technology
}

\begin{abstract}
Deindustrialisation is the phenomenon of the secondary sector growing more slowly than the rest of the economy, whether measured by share of GDP or of employment. Almost all rich $O E C D$ countries have been experiencing it. However New Zealand has been deindustrialising faster than the OECD average (even if the energy based industries developed in the 1980's are included). The paper describes the phenomenon, and discusses why it has happened. ${ }^{2}$
\end{abstract}

Keywords: deindustrialisation, manufacturing, industrial policy, economic growth, economic structure.

New Zealand is not usually thought of as an industrial society. In the nineteenth century it did not have the dark satanic mills of Europe from whence fled the Pakehas' ancestors. Today its factories are usually smaller than those of most industrial societies, and their products do not have the prestige that symbolizes modern industry. The international and national vision of New Zealand is a rural country, whose economy specializes in rural products.

Certainly by international standards New Zealand's modern farming sector is exceptionally important. Yet for most of the post-war era the size of New Zealand's industrial sector has been comparable to that of other OECD countries, with a manufacturing sector larger than the agriculture sector by contribution to GDP since the 1950's, and by employment since the 1940's. In the early part of the postwar era the majority of the manufacturing sector created jobs and saved foreign exchange, thus contributing to goods and services to material welfare and to the full employment of psychological welfare. Much was produced behind high levels of border (and internal) protection, although economists disputed the extent that this protection was beneficial or detrimental to overall economic welfare. A smaller part of manufacturing was directed at adding value to the key foreign exchange earning pastoral exports.

From 1966, following a fall in the terms of trade which made pastoral exporting less attractive, the manufacturing exporting sector developed from its processing of terms of the traditional exports, to adding value to new primary products of forestry, fishing, mining, and non-pastoral farm products, together with some general manufacturing mainly to Australia but to other nearby countries in Asia and the $\mathrm{Pa}$ cific. Manufacturing experienced another major change in the early 1980's, when the energy surpluses from the Maui gas field and the Waitaki basin hydro-scheme created "think big" energy intensive production, which were typically substitutes for imports.
But from the 1970's, border and internal protection had been systematically lowered (very quickly after 1984), so that today there is very little general manufacturing competing against imports. It either exports - value added to primary processing, manufactured commodities, or elaborately transformed manufactures - or provides products which cannot be practically imported. Nevertheless, until the mid 1980's the relative size of the sector remained roughly constant at a 21 to 24 percent contribution to GDP, and a 23 to 27 percent share of the labour force. Thereafter, both shares began falling. The employment share is now about 15 percent, and the GDP contribution share is under 19 percent. This is "deindustrialization".

This paper details the change, sets down the major reasons for it, examines the macro-economic implications which suggest the decline should be arrested, and suggests policies to do this. While some deindustrialization is inevitable, we shall see that its rapidity is a threat to the viability of the New Zealand economy.

\section{The pattern of deindustrialization}

This study uses two measures of the relative size of manufacturing and other sectors. The first is the contribution the sector makes to GDP. The second is the share of the sector's employment in national employment (the labour force less the unemployed). Statistical measurement always involves complicated issues. In particular these indicators are for long periods, so they are especially prone to conceptual and statistical drift. But the trends are likely to be broadly correct.

\section{Manufacturing's contribution to GDP share}

As Table 1 shows, between the end of the First World War and the mid 1980's, the Manufacturing Sector's contributed between 21 to 24 percent to GDP, averaging 22.4 percent between 1954/5 and 1983/84. But from the mid 1980's, 
Table 1. Contribution to Production Percent of GDP

\begin{tabular}{|c|c|c|c|c|c|c|c|c|c|c|c|c|}
\hline & $1919 / 20$ & $1929 / 30$ & $1938 / 39$ & $1952 / 53$ & $1959 / 60$ & $1964 / 65$ & $1969 / 70$ & $1974 / 75$ & $1979 / 80$ & $1983 / 84$ & $1989 / 90$ & $1994 / 95$ \\
\hline Agriculture & 29.8 & 26.2 & 23.2 & 22.1 & 18.0 & 14.2 & 11.7 & 7.7 & 10.1 & 7.3 & 7.0 & 6.2 \\
\hline Other Primary & & & 2.9 & 3.9 & 4.3 & 3.7 & 4.3 & 3.0 & 5.1 & 5.5 & 6.8 & 6.0 \\
\hline Manufacturing & 21.6 & 23.7 & 21.7 & 21.1 & 21.8 & 22.5 & 22.5 & 23.3 & 23.3 & 22.3 & 18.8 & 18.9 \\
\hline Construction & 4.0 & 6.6 & 8.0 & 7.1 & 7.2 & 6.3 & 5.7 & 7.4 & 4.6 & 5.1 & 4.7 & 5.2 \\
\hline Domestic Trade & & & 15.2 & 16.4 & 18.7 & 21.9 & 20.7 & 21.9 & 20.0 & 20.6 & 14.9 & 16.5 \\
\hline Transport \& Com & & & 5.8 & 8.5 & 7.4 & 7.4 & 8.0 & 7.6 & 7.9 & 8.5 & 8.7 & 8.7 \\
\hline Finance & & & 7.7 & 7.3 & 8.2 & 8.6 & 9.1 & 9.9 & 9.6 & 11.1 & 15.4 & 15.1 \\
\hline Other Services & & & 15.5 & 13.6 & 14.4 & 15.4 & 18.0 & 19.2 & 19.4 & 19.5 & 23.7 & 23.4 \\
\hline TOTAL & 100.0 & 100.0 & 100.0 & 100.0 & 100.0 & 100.0 & 100.0 & 100.0 & 100.0 & 100.0 & 100.0 & 100.0 \\
\hline
\end{tabular}

Source: Easton In Stormy Seas, p.140, updated with SNZ data.

Note: The definitions are aligned, as far as possible to the Philpott \& Nana definitions of 1959/60 to 1983/84.

Table 2. Share of Employment

\begin{tabular}{|c|c|c|c|c|c|c|c|c|c|c|c|c|}
\hline & 1936 & 1945 & 1951 & 1956 & 1961 & 1966 & 1971 & 1976 & 1981 & 1986 & 1991 & 1996 \\
\hline Agriculture and hunting & 24.7 & 19.0 & 17.7 & 15.6 & 13.8 & 12.5 & 10.8 & 9.5 & 10.1 & 10.8 & 9.5 & 9.8 \\
\hline Forestry \& fishing & 1.9 & 1.2 & 0.7 & 0.6 & 0.7 & 0.7 & 0.9 & 0.9 & 1.1 & 1.1 & 0.8 & \\
\hline Mining \& quarrying & 1.9 & 1.2 & 1.1 & 0.9 & 0.8 & 0.6 & 0.5 & 0.4 & 0.4 & 0.4 & 0.3 & 0.3 \\
\hline Manufacturing & 17.1 & 20.5 & 24.1 & 23.8 & 25.0 & 26.8 & 25.4 & 24.7 & 24.2 & 21.0 & 16.8 & 15.2 \\
\hline Electricity, gas \& water & 0.9 & 1.0 & 1.1 & 1.3 & 1.3 & 1.3 & 1.2 & 1.2 & 1.2 & 1.0 & 0.8 & 0.6 \\
\hline Building \& construction & 7.5 & 6.7 & 8.5 & 10.0 & 9.7 & 9.3 & 8.5 & 9.1 & 6.7 & 6.8 & 6.2 & 6.1 \\
\hline Wholesale, retail, restaurant & 13.5 & 11.9 & 14.2 & 15.3 & 15.7 & 14.8 & 17.9 & 17.5 & 17.0 & 19.4 & 20.7 & 23.8 \\
\hline Finance, insurance, property & 5.1 & 5.7 & 4.6 & 5.0 & 5.2 & 5.9 & 5.9 & 6.4 & 7.1 & 7.4 & 11.8 & 14.0 \\
\hline Transport, storage, comm & 10.1 & 11.0 & 10.6 & 10.3 & 10.0 & 9.6 & 9.3 & 9.0 & 8.4 & 8.2 & 6.2 & 5.7 \\
\hline Government & 2.6 & 9.4 & 4.2 & 3.9 & 3.9 & 3.8 & 4.2 & 4.8 & 6.0 & 5.2 & 6.1 & 4.4 \\
\hline Personal \& Private Services & 9.2 & 5.1 & 6.0 & 5.4 & 5.2 & 4.5 & 3.0 & 2.6 & 2.8 & 2.7 & 2.3 & 4.0 \\
\hline Other Services & 5.5 & 7.3 & 7.1 & 7.9 & 8.8 & 10.1 & 12.4 & 13.8 & 15.1 & 15.9 & 18.4 & 16.1 \\
\hline TOTAL EMPLOYMENT & 100 & 100 & 100 & 100 & 100 & 100 & 100 & 100 & 100 & 100 & 100 & 100 \\
\hline
\end{tabular}

Source: Population Censuses.

Note: Definitions change slightly between some Censuses. 
Table 3. Manufacturing share of value added

\begin{tabular}{lclc}
\hline 1974 & \% & 1993 & \% \\
\hline Luxembourg & 41.8 & Korea & 27.0 \\
Germany & 36.0 & Japan & 25.5 \\
Portugal & 33.8 & Germany & 24.9 \\
Japan & 33.6 & Czech Republic & 24.4 \\
Austria & 30.8 & Portugal & 23.9 \\
Belgium & 30.8 & Finland & 21.1 \\
Italy & 28.6 & Turkey & 20.8 \\
France & 27.9 & Austria & 20.5 \\
Spain & 27.7 & OECD & 20.4 \\
Sweden & 27.2 & Spain & 20.3 \\
United Kingdom & 27.1 & Italy & 20.0 \\
Finland & 26.3 & France & 19.5 \\
Korea & 25.7 & Luxembourg & 19.5 \\
Netherlands & 25.0 & Belgium & 18.4 \\
New Zealand & $\mathbf{2 4 . 1}$ & United Kingdom & 18.1 \\
Mexico & 24.0 & New Zealand & $\mathbf{1 8 . 1}$ \\
United States & 23.3 & Sweden & 18.0 \\
OECD & $\mathbf{2 2 . 9}$ & United States & 17.8 \\
Ireland & 22.8 & Netherlands & 17.8 \\
Norway & 21.9 & Mexico & 17.5 \\
Australia & 21.3 & Denmark & 16.5 \\
Canada & 19.7 & Australia & 14.5 \\
Turkey & 18.3 & Greece & 13.2 \\
Greece & 18.2 & Iceland & 12.8 \\
Denmark & 18.1 & Norway & 11.5 \\
Iceland & 13.0 & Canada & \\
Czech Republic & & Hungary & \\
Hungary & & Ireland & \\
Poland & & Poland & \\
Switzerland & & Switzerland & \\
\hline
\end{tabular}

Source: $\mathrm{OECD}$

that share deteriorated to 18.8 percent in $1989 / 90$ and 19.4 percent in 1994/95. This apparent stability in the 1990's does not represent a structural change so much as a cyclical recovery in commodity prices for base metals and forestry products. Preliminary figures indicate that the structural decline has continued since.

The decline represents about 3.5 percentage points of GDP. That does not simply convert into a 3.5 percentage fall in GDP. Because manufacturing purchases inputs and generates flow-on economic activity the impact on GDP is greater.

There is good reason to expect the share will continue to fall. Two major factors are the closure of the car assembly and associated component industry as a result of the 1998 tariff elimination, while further plant closures are threatened as a result, of the proposed tariff reductions after 2001.

\section{Manufacturing's contribution to employment}

As Table 2 shows, manufacturing's share in employment exceeded 24 percent of the total for much of the postwar era, although perhaps the share was declining at around 1 percentage point a decade from the mid 1960s. That the average employment share from $1954 / 55$ to $1983 / 84$ was about two percentage points higher than the manufactur- ing's share in GDP indicates that labour productivity in manufacturing was a little lower than the economy wide average. This was because manufacturing has not been as capital intensive as agriculture, mining, energy, communications, and housing. That the employment share had been falling slowly while the output share had been broadly constant reflects the labour productivity rising faster in this sector than on average.

From the mid 1980's, the employment share begins falling quickly - to 16.8 percent in 1991 and 15.2 percent in 1996. If the employment share had followed the gently falling trend line of the pre $1986 \mathrm{era}$, it would have been closer to 22 percent, some 7 percentage points higher. Today, manufacturing has the lowest proportion of total employment since the 1860 's when gold prospecting drained off other domestic production. In recent years, the employment share fall has been faster than the added value fall, so manufacturing labour productivity has risen sharply and is now above the economy wide average.

\section{The international evidence}

That the New Zealand economy has been rapidly deindustrializing since the mid 1980 's parallels an interna-

Table 4. Manufacturing share of profit

\begin{tabular}{lclr}
\hline 1960-1973 & $\%$ & 1990-1995 & $\%$ \\
\hline Switzerland & 37.7 & Czech Republic & 31.3 \\
United Kingdom & 36.8 & Germany & 29.2 \\
Germany & 35.8 & Austria & 25.3 \\
Luxembourg & 33.5 & Korea & 25.1 \\
Austria & 31.9 & Portugal & 24.0 \\
Belgium & 31.5 & United Kingdom & 23.8 \\
Sweden & 30.1 & Japan & 23.7 \\
Netherlands & 28.4 & Finland & 23.7 \\
Australia & 28.0 & Denmark & 22.5 \\
France & 27.6 & Italy & 22.4 \\
Finland & 27.5 & Switzerland & 21.8 \\
New Zealand & $\mathbf{2 7 . 2}$ & Spain & 20.8 \\
OECD & $\mathbf{2 7 . 0}$ & Belgium & 19.9 \\
Italy & 26.8 & Ireland & 19.7 \\
United States & 26.4 & OECD & $\mathbf{1 9 . 5}$ \\
Norway & 25.9 & Sweden & 19.2 \\
Spain & 25.8 & France & 19.1 \\
Japan & 25.1 & Greece & 17.3 \\
Canada & 24.1 & Iceland & 17.3 \\
Denmark & 23.6 & Netherlands & 17.3 \\
Portugal & 23.6 & New Zealand & $\mathbf{1 7 . 0}$ \\
Iceland & 23.3 & United States & 16.9 \\
Ireland & 19.1 & Norway & 15.1 \\
Greece & 14.5 & Canada & 15.0 \\
Turkey & 9.2 & Turkey & 14.6 \\
Czech Republic & & Australia & 14.1 \\
Hungary & & Hungary & \\
Korea & & Luxembourg & \\
Mexico & & Mexico & \\
Poland & & Poland & \\
\hline & & & \\
\hline
\end{tabular}




\section{Figure 1. Manufacturing share of added value}

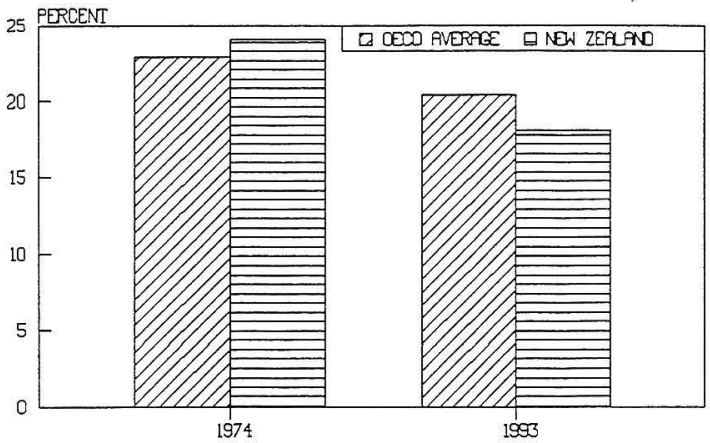

tional phenomenon. Table 3 shows that New Zealand ranked 15th out of 25 in contribution to GDP terms in 1974, with a share of 24.1 percent. This was a little above the OECD average share of 22.9 percent. By 1993 New Zealand was still 15 th, but its share of 18.1 percent was below the OECD average of 20.4 percent. The evidence of the table is that most OECD countries experienced deindustrialization (Korea is the marked exception), but on the contribution to GDP measure New Zealand was deindustrializing faster (Figure 1).

Table 4 shows that New Zealand ranked 12th in employment terms in the 1960-1973 period, with 27.2 percent, just above the OECD average of 27.0 percent. By the 1990 to
1995 period New Zealand was 20 th at 17.0 percent, well below the OECD average of 19.5 percent. On this measure the $O E C D$ also experienced deindustrialization, but again New Zealand's was one of the most drastic (Figure 2).

A complication in interpreting the comparative data arises from the development of the energy intensive development which took place in the early 1980's. In 1974/75 the chemical subsector contributed 2.0 percent to GDP, but in 1994/ 5 it was 2.6 percent. If it had grown as slowly as the rest of manufacturing, the manufacturing sector would have been over one percentage point of GDP smaller, and New Zealand manufacturing would have been more like 20th on the contributor to GDP in the mid 1990's OECD league table.

\section{Figure 2. Manufacturing share of employment}

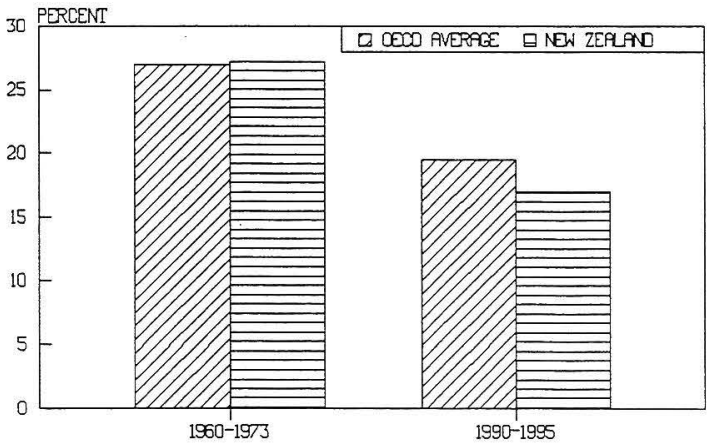


Thus "Think Big" obscures the high rate of deindustrialization of the New Zealand economy.

\section{Why the deindustrialization?}

Any explanation of why the New Zealand manufacturing sector has been getting relatively smaller needs to address two issues. Why does the phenomenon occur elsewhere in the world too (this section), and why New Zealand's is experiencing a greater one than most (next section).

There is a well elaborated theory of the structural change which most economies experience as they develop. Initially the primary sector share of economic activity contracts as workers shift to more productive and higher paid (often urban) sectors, and as relative demand for primary products, especially food, diminishes.

These mechanisms do not quite apply to New Zealand generally New Zealand agriculture is (and has been) a very productive part of the economy, while as a major food exporter New Zealand farming is not as pressed by the diminishing share of foodstuffs in local final consumption. Nevertheless since before the war the share of farming in economic activity has been diminishing (Tables 1,2$)$. The deceleration of the decline of the whole of the primary sector has not been as great, because forestry and deep sea fishing has expanded, and new hydroelectricity and hydrocarbon energy sources were exploited. The service sector absorbs the resources released from the primary sector as the share of services rises in final consumption, and because the primary and secondary sectors outsource work to the service sector (as when a farmer hires an accountant). Meanwhile the manufacturing sector retains its share of economic activity.

There are exceptions to the general pattern. A resource boom, as occurred in Australia and Norway, will increase the size of the primary sector, and squeeze the manufacturing sector, because it is difficult to import services which tend to be produced at the point of sale. This distinction between that which can be transported between point of production and of sale/consumption, and that which has to be produced at the point of sale/consumption is a key in the separation of the economy into a tradeable and nontradeable sector, which becomes central in the Section 3 . There are manufacturing products where transport costs have been so high that they are located close to their consumers. The plethora of local breweries half a century ago illustrates this, but their demise also illustrates that transport and communication costs have dramatically lowered in recent years - a key element in the story. It is also true that some services are tradeables, most obviously the tourist industry.

These changes are sometimes summarized as "economic globalisation", which involves production shifting to locations of minimum cost. This has especially involved low cost, labour intensive manufacturing production moving to East Asia, with the result that the manufacturing sector share of economic activity declines in the local economy and rises in East Asia (as was reported in regard to South Korea). There may also be an element that manufacturing's share in final consumption is declining as increasingly affluent consumers increase their demand for services.

So in recent years manufacturing's share in OECD economic activity has been decline. (The share of manufacturing in nominal OECD GDP fell from 28.6 percent in 19601973 to 20.4 percent in 1990-95. The figures for employment share are 27.0 percent and 19.5 percent respectively.) This deindustrialization seems to be a long term structural change. It is unlikely that New Zealand can resist the trend, any more than it was able to resist the long term trend of the agricultural's falling share of economic activity. But that does not explain New Zealand's greater deindustrialization.

\section{The faster deindustrialization of New Zealand}

Following are three closely related explanations for New Zealand's faster deindustrialization.

\section{The weakness of microeconomic industrial policy}

As will become clear in the next section, the tradeable sector has a special role in the growth process of a small open economy, because it earns (or conserves) the foreign exchange needed to pay for imports. Current economic policy does not recognize this role. It professes to treat all sectors equally although, in practice, policy is pro-finance at the expense of production. Moreover this claimed neutrality towards the various production sectors ignores their fundamental differences. Phenomena such as industry externalities and the need for long term investment, and needs such as infrastructure are ignored in favour of an idealised impractical theory which most closely mirrors the situation of the finance sector, and as a result benefits that sector.

This ideologically driven vision has meant that the government has no industry policy. Instead it has stripped away industry support, without any clear understanding of its role or the positive benefits that the economy obtains from it. A good example has been the withdrawal of border protection at a rate faster than the industry could adjust, without there being any alternative employment. Coupled with the unfavourable macroeconomic environment from an overvalued exchange rate and high interest rates the manufacturing sector in particular, and the tradeable sector in general, has suffered.

To simplify, a manufacturing sector makes STMs (simply transformed manufactures) and ETMs (elaborately transformed manufactures). Strictly the critical difference is the processes involved and any manufacture may be a mix of STP(rocesse)s and ETP(rocesse)s. Typically the level of the last process usually defines whether the final good is an STM or an ETM. The distinction is mainly about the sophistication of the work skills and quality standards involved in the production process. Given access to the raw materials or the components, STPs can be manufactured 


\section{Figure 3. Export volumes}

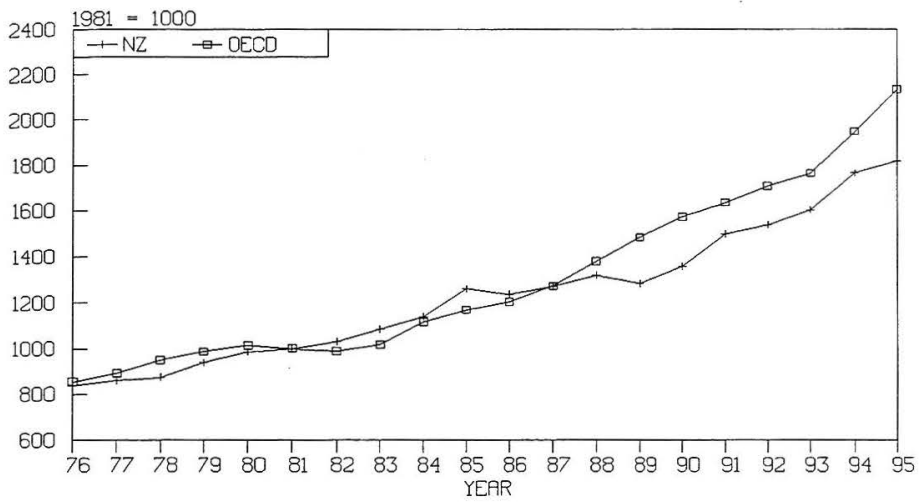

Source: OECD (Note: OECD countries differ before 1981)

offshore by low skilled workers. In effect a New Zealand STP involves competing against low paid Asian and other workers. Ultimately there is little future in New Zealand industry attempting an industrialisation strategy based on STPs. While some workers' wages in STP industries may be subsidized one way or another by the state via border protection, fiscal subsidies, or some other intervention, the entire workforce cannot be so subsidized. In any case low wage work (or a high cost goods to consumer, which is often the consequence of the interventions) has the inevitable consequence of the workers migrating to a high wage economy such as Australia.

An indication of how unsatisfactory the New Zealand ETM performance is appears in some New Zealand Manufacturers Federation estimates. They found that in the December 1995 year, only 16.8 percent of all exports of goods were ETMs, just over half of which went to Australia. However Australia exported over a \$1b more ETMs to New Zealand, than New Zealand did to Australia. The structure of New Zealand exporting remains predominately primary products and commodities (albeit more diversified in type, destination, and added value than 30 years ago). Moreover unlike most other OECD economies, the share of ETMs in New Zealand's exports has not grown since 1985 . Commodity manufactures (STMs) expanded in the 1980's with the commissioning of the energy intensive plants, and so over the decade they grew faster than ETMs by about 4 percent p.a.

This partly reflects natural advantage, but it also leaves New Zealand as a commodity exporter vulnerable to the vagaries of international trade policy, and to international shocks, especially sudden deteriorations in the terms of trade. The
ETM failure is a major reason why New Zealand's deindustrialization has been stronger than that of the OECD average.

\section{The macroeconomic repression of the tradeable sector}

In this subsection, we shall look at the tradeable sector of which the manufacturing sector is an important part, and only of goods for there is no suitable data on services. Figures 3 and 4 graph the volume of (i.e. constant price or real) exports and imports since 1976 . They suggest that up to 1985 New Zealand exports grew faster than the OECD, and up to 1986 (or 1988) New Zealand imports grew slower. Allowing for the import substitution effect of the energy intensive industries that came on stream in the mid 1980 's, the import turning point is probably 1985 too. After 1985 New Zealand exports grew slower and imports grew faster than the OECD average. By no means coincidentally, New Zealand GDP grew slightly faster than the OECD in the pre 1985 period, and slower in the post 1985 period.

Not only was there an increasingly antagonistic industrial policy, there was also a hostile macro-economic environment. While the removal of export incentives and tariffs requires a fall in the real exchange rate to maintain export sector profitability, the real exchange rate rose sharply. This not only transferred the benefits of the higher terms of trade to the domestic sector, but was the central element of the disinflation of the economy, as the New Zealand inflation rate shifted from among the highest in the OECD, to one of the lowest.

The consequences on the tradeable sector was that its profitability was undermined, while importing became more 
attractive. Export volume growth slowed down and import volume growth accelerated. The high import volume growth in comparison to the OECD average is all the more astonishing given the lower GDP growth of the New Zealand economy. New Zealand's import penetration was rising even faster. The slower growth of the tradeable sector inevitably translated into slower economic growth.

At the crucial time when macroeconomic policy was pressuring the tradeable sector its productivity growth performance deteriorated. Productivity growth in the exportable sector slowed down in the late 1980's. (Importable sector productivity growth is cyclical but an underlying secular slowdown from the early 1990 's is also evident.) This was partly the failure of a supportive industrial policy, like that in the 1970's and early 1980's which had encouraged expansion, diversification, and productivity growth, compounding the poor macroeconomic environment. Exporting is not an activity which can be conveniently turned on and off like a tap, or a financial transaction. It is not just that domestic production requires investment and process development. The action of exporting of sophisticated products requires market development in the locality including the building of a distribution network, and market identification and reputation. It is hard to quantify the deterioration, but anecdotally it is reported that much export development fell off from the mid 1980's, as exporters were profit squeezed and facing high borrowing rates.

This market development point applies less to commodity exporting, which typically involves a less sophisticated product, with a simple specification, usually going to a manufacturer as a product input. In any case, an overval- ued exchange rate discourages domestic value adding, and so the primary product is more likely to be exported as a commodity, with a minimum of processing. Thus the New Zealand economy remained trapped into a colonial export mode, of producing the materials that the metropolitan country would convert into sophisticated products. Commodity exports remain more vulnerable to fluctuations in market conditions and prices.

\section{The increasing dominance of the finance and business services sector}

Table 1 and 2 showed that the finance, insurance, real estate, and business services sector increased its share of activity from the mid 1980 s. The contribution to GDP share grew slower than the employment share underlying the poor labour productivity performance of the sector over the period. In 1996 the finance sector employment share was 14.0 percent compared to 15.2 percent for manufacturing. While the tradeable sector on which the nation's economic prosperity has been in decline, the financial sector has expanded. Between the 1986 and the 1996 Census the numbers employed in the Finance, Insurance and Property sector increased 104,000, (or by 83.9 percent) over the decade, while those in the rest of the economy grew only 27,000 (2.0 per cent). (The top three tradeable sectors lost 76,000 jobs, or 15.6 percent). If current trends continue the finance and business services sector will soon be employing more than the manufacturing sector in the near future.

Now the finance and business services sector has a crucial role in a well functioning economy. As its name says, that function is mainly to service the rest of the economy. In

Figure 4. Import volumes

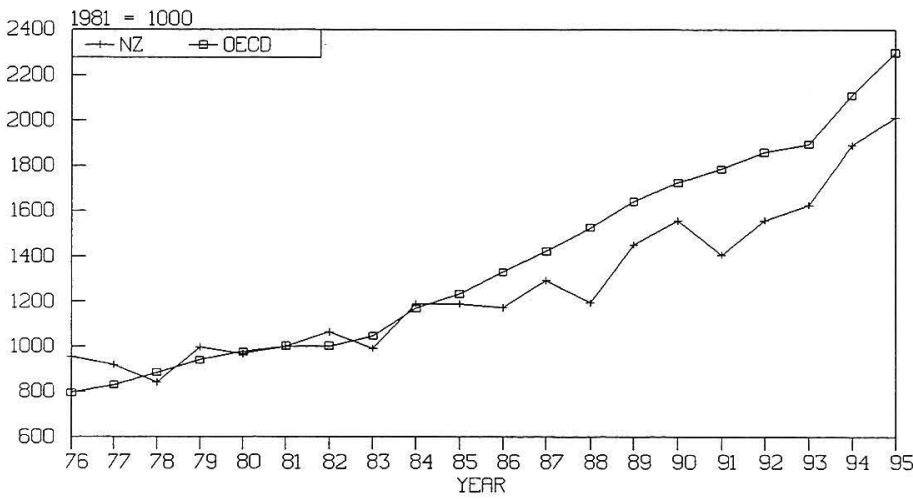

Source: OECD (Note: OECD countries differ before 1981) 
1981 each worker in the sector was servicing 13.5 other workers. By 1996 each sector worker was servicing 6.2 workers.

One factor has been outsourcing of finance and business services (which once took place within the productive firm (or farm) or in the public sector. In addition some consumer financial activities have increased. But government policy has been supportive of financiers in contrast to its antagonism to the tradeable sector.

Not only has the finance sector filled deindustrialization's value added and employment gap, but it also fills the foreign exchange gap. Because the tradeable sector is no longer earning and conserving sufficient foreign exchange, foreign exchange receipts are supplemented by borrowing, via the finance sector. Unlike earning the funds by tradeable production, the borrowing strategy of the financial sector is not sustainable.

\section{The ongoing balance of payments crisis}

Traditionally the management of the New Zealand economy has included the Balance of Payments rule that the annual current account deficit (a.k.a external deficit) should average about 3 percent of GDP, with a comfort zone of 1 to 5 percent. A rise (or expectation of rise) of the deficit above 5 percent triggered a macroeconomic policy response, usually aimed to reduce imports by a reduction in aggregate demand or by increased import controls. In that traditional economy, the government was the main borrower for the overseas funds to cover the deficit, so the comfort zone represented an assessment of what could be reasonably be borrowed in any year before lenders became uneasy. The underlying theory pointed out that if the net foreign current payments deficit percentage exceeded the nominal GDP growth rate, the Net Foreign Debt to GDP ratio would rise.

At the time of presentation of the paper the external deficit was about 7 percent of GDP, perhaps moving slowly back to just above 6 percent of GDP, according to the more optimistic forecasters. This is outside the traditional comfort zone, so we may expect foreign lenders to get increasingly anxious.

We can explore how the productive economy might respond given the task of halving a external deficit, by simulating a simple model of an economy which looks a bit like the New Zealand economy in 1998 , with an external deficit of 8 percent of GDP. I identify four strategies, each of which aimed to get the deficit down to 3 percent of GDP. Here is a summary of the findings.

\section{Reducing aggregate domestic demand}

Suppose aggregate demand in the economy was reduced (with no extra exporting). Aggregate domestic demand had to decrease 9.5 percent and production 7 percent to get the required ( 8.5 percent) reduction in imports. The parameters and assumptions can be varied, but the basic conclusion remains. Obtaining the 3 percent target external deficit by reducing imports from cutting aggregate demand, requires very large cuts which would almost certainly generate record post-war unemployment.

\section{Increasing exports}

Suppose exports were to increase, generating some extra economic activity, which increases imports. Thus the export increase would have to be more than 3 percentage points of GDP. The model has exports increasing 11.3 percent, production by 4.5 percent, imports by 1.1 percent, and domestic expenditure by 1.4 percent to get down to the 3 percent of GDP external deficit target. This may not be very feasible (see below). At this point it should be noted, the strategy vitally depends upon a very tight fiscal stance, with additional tax revenue (and savings) not being spent.

\section{Import replacement}

Suppose import replacement increased but there was no change in exports. The extra production in the economy would draw in more imports, so spending would go up, as well as production. In summary the simple model predicts a 5.3 percent increase in production, a 2.1 percent increase in expenditure, and a reduction in the propensity to import of 12.9 percent. Again it requires a very tight fiscal stance.

\section{Growth}

Thus far it has been assumed that the changes are instantaneous. The fourth scenario, using a different model from the previous three, assumes that GDP grows at 3 percent p.a., the average propensity to import remains constant, and exports grow at 4.5 percent p.a., considerably higher than the current forecast of 3 percent p.a. In this projection it takes eight years before the economy reaches the 3 percent of GDP external deficit, although it enters the comfort zone of less than 5 percent of GDP after three years. Note again the fiscal stance has to remain tight.

The simulations illustrate some general propositions:

1. Simply cutting domestic spending - be it by government spending cuts, higher taxes, or increased savings - is too draconian. It would result in a major contraction and record unemployment. But all successful policies require a degree of self-discipline of domestic spending.

2. Slow adjustment requires considerable confidence by foreign investors over a longish period. Further shocks could delay the return to the comfort zone, and confidence may not necessarily hold. A slow adjustment is a high risk strategy.

3. The increases required in the tradeable sector are substantial. Are they feasible?

There are significant short-term supply-side constraints to many New Zealand tradeable producers. Farming, fishing, and forestry products face biological limitations. The production capacity of many manufacturers and service exporters is fixed or difficult to change quickly. Much of the import substitution component of manufacturing has al- 
ready been gutted by lower protection, while the little which remains faces a similar threat.

Thus any short term export supply response relies on general manufacturing and tourism. Whether they have the production capacity to grow considerably faster is debatable. There may not be a lot of spare capacity for the sort of growth that is required. Moreover modem exporting requires considerable market development. Even ignoring that most major Asian export markets are in disarray, profitability has been so unfavourable in recent years that there has been insufficient market development.

In summary the prospects that the tradeable sector can quickly save the New Zealand economy from an eventual severe balance of payments crisis are not great.

\section{Conclusion}

While New Zealand continues with its current policies, it continues to face the prospect of low economic growth, based on commodity exports vulnerable to international trading conditions, with its best people migrating, and a socially and culturally impoverished nation. Few of New Zealander's ancestors - brown, white, and yellow - came with such a mean vision.

There is a different approach: one which can be illustrated with industrial policy. It involves a vision of New Zealand as a full member of the international community, active in all its transactions - peace, human rights, cultural, sporting, intellectual and social as well as economic - with a firm commitment to New Zealand as an independent nation, as autonomous as international responsibilities permit, flourishing in the interests of all the diversity and energy that makes up the ordinary New Zealanders.

There is a national vision which desires a green and pleasant land. But without manufacturing, a deindustrialized New Zealand would be a severely depopulated ones, isolated from the vibrancy of international metropolitan life.

\section{References / Notes}

1. Economic and Social Trust in New Zealand. A precipitant of this work was the statement that ".. from the 1950 's to the mid-1970's the manufacturing sector accounted for a growing share of employment in New Zealand - from 4 percent to just under 26 percent. With deregulation and lower trade barriers, this number fell rapidly to some 18 percent by 1992." (The New Zealand Employment Contracts Act: Its Enactment, Performance and Implications, Californian Western International Law Journal, Fall 1997) Manufacturing's share of employment was 24 percent in 1951 and 1956.

2. See Easton, B.H. (1997) In Stormy Seas University of Otago Press, Chapter 14.

3. Easton, B.H. (1996) Brendan Thompson's New Zealand Work Force Series, in Morrison, P.S. (ed), Labour Employment and Work in New Zealand: Proceedings of the Seventh Conference, Institute of Geography, Victoria University of Wellington, p.277-285.

4. My views on "Think Big" will be found in, In Stormy Seas. Suffice to say here that while Chapter 11 expresses numerous reservations, it points out most of the critics are stronger on rhetoric than analysis.

5. And back into the nineteenth century according to Brendan Thompson's census based industrial employment tables. Easton (1996) op cit.

6. It is arguable that the two periods are even more distinct, because some of the new exports of the mid and late 1980's were the consequences of earlier decisions, such as the heavy subsidization of horticulture in the 1970 's and early 1980's. A similar effect on the import substituting side has already been mentioned.

7. In Easton,B.H. (1997) Stormy Seas.

8. See Easton, B.H. (1998) Microeconomic Reform: The New Zealand Experience, Microeconomic Reform and Productivity Growth: Workshop Proceedings, Productivity Commission and ANU.

9. For instance, given the way ACC is levied, some manufacturers have set up separate service companies. Information technology has been another potent cause of outsourcing.

10. In Easton, B. (1997). Stormy Seas

11. In the standard notation

$$
\begin{array}{ll}
-\mathrm{C}+\mathrm{I}+\mathrm{G} & =106 \\
-\mathrm{X} & =30 \\
-\mathrm{M} & =36 \\
-\mathrm{Y}(\mathrm{GDP}) & =100
\end{array}
$$

With the marginal propensities as follows:

$$
\begin{array}{ll}
\text { - } \operatorname{tax} & =.4 \\
\text { - import } & =.5 \text { out of disposable income } \\
\text { - consume \& invest } & =.5 \text { out of disposable income. }
\end{array}
$$

\section{Author}

Brian Easton is a Consultant,

18 Talavera Tce,

Kelburn,

Wellington.

E-mail: eastonbh@compuserve.com 